\title{
Investigation of the effects of fascia lata on neochondrogenesis in a rabbit model
}

\author{
Fasia latanın neokondrogenezis üzerine olan etkilerinin tavşan modelinde araştırılması \\ Şengül Yılmaz', Özge Bilkay², İsmail Özdemir³, Arzu Avcı', Işıl Adadan Güvenç ${ }^{5}$ \\ ${ }^{1}$ Department of Otorhinolaryngology, Denizli Government Hospital, Denizli, Turkey \\ ${ }^{2}$ Department of Otorhinolaryngology, Alsancak Government Hospital, Izmir, Turkey \\ ${ }^{3}$ Department of Otorbinolaryngology, Gazi Hospital, Izmir, Turkey \\ ${ }^{4}$ Department of Pathology, Izmir Katip Çelebi University Medical Faculty, Izmir, Turkey \\ ${ }^{5}$ Department of Otorbinolaryngology, Başkent University Hospital, Izmir, Turkey
}

\begin{abstract}
Objective: The impact of fascia lata on neochondrogenesis placed between both leaflets of the perichondrium after full thickness submucoperichondrial cartilage resection was investigated in a rabbit septum model.

Methods: Twenty adult New Zealand rabbits were studied in two groups with equal number of animals in each group. Full thickness cartilage with an area of $1 \mathrm{~cm}^{2}$ was resected to create a cartilage defect in all rabbits. Autogenous fascia lata was interposed between both leaflets of the perichondrium and the surgical field was closed (fascia lata group). No material was interposed between both leaflets of the perichondrium of the defective area (control group). Rabbits were sacrificed on postoperative 90th days and their septa were totally excised. Neochondrogenesis was investigated histopathologically with a light microscope. The preparations were evaluated as for thickness of newly formed cartilage (in mm), inflammatory reaction and presence of macroscopic perforation.

Results: Thickness of the cartilage in the fascia lata group was significantly greater than that of the control group ( $M-W-U=15,000, \mathrm{p}<0.05)$.

Conclusion: Use of fascia lata in the acceleration of perichondrial neochondrogenesis can result in successful outcomes in the repair of cartilage defects.
\end{abstract}

Keywords: Neochondrogenesis, nasal septum, fascia lata.

Cartilage tissue has a mesenchymal origin and consists of chondrocytes and matrix. Basic function of this tissue is to protect and support soft tissues. ${ }^{[1,2]}$ Growth and prolifera-

\section{Özet}

Amaç: Submukoperikondrial tam kat kıkırdak rezeksiyonu sonrası her iki perikondrium yaprağı arasına konan fasia latanın neokondrogenezis üzerine olan etkilerinin araştırılması.

Yöntem: Yirmi adet genç erişkin Yeni Zelanda tavşanı eşit sayıda iki gruba ayrıldı. Her tavşanın nazal septumlarından $1 \mathrm{~cm}^{2}$ lik tam kat kıkırdak rezeksiyonu yapıldı. Oluşan kıkırdak defektine ilk grupta tavşanın kendisinden alınan fasia lata submukoperikondrial olarak yerleştirildi (fasia lata grubu). Diğer gruba herhangi bir materyal konmadı (kontrol grubu). Operasyon sonrası 90. günde defekt bölgesini de içine alacak şekilde subtotal septum rezeksiyonu yapıldı. Yeni kıkırdak oluşumu histopatolojik olarak, 1şı mikroskobuyla incelendi. Değerlendirmede perikondrium kökenli yeni kıkırdak oluşumu, iltihabi reaksiyon ve nekroz, makroskopik olarak da perforasyon oluşumu göz önüne alındı.

Bulgular: Fasia lata yerleştirilen çalışma grubunda oluşan yeni kıkırdak dokusu kontrol grubuna oranla anlamlı derecede fazla bulundu (M-W-U=15.000, p<0.05).

Sonuç: Fasia latanın neokondrogenezise olan katkısı, kıkırdak defektlerinin onarımında bu materyalin kullanılabilirliğini desteklemektedir.

Anahtar sözcükler: Neokondrogenezis, nazal septum, fasia lata.

tion of chondrocytes are realized through cellular proliferation from perichondrial tissue of the young cartilage which has chondrogenic properties (appositional growth)
Correspondence: Şengül Yılmaz, MD. Department of Otorhinolaryngology, Denizli Government Hospital, Denizli, Turkey.

e-mail: sengulyilmaz78@gmail.com

Received: April 30, 2014; Accepted: June 2, 2014
Online available at:

www.jmedupdates.org doi:10.2399/jmu.2014002002 QR code: 
and via mitotic division of available young chondrocytes (interstitial growth). When cartilage is damaged chondroblasts migrate to the injured region and form a new cartilage tissue. If a larger damaged area is present and perichondrial regeneration is not fast enough to compensate the loss, then the defect cannot be repaired completely and heals with formation of a scar tissue..$^{[2,3]}$

Perichondrium wraps the cartilage and forms an interface between the cartilage and the surrounding tissues. Perichondrium provides support for the avascular cartilage ${ }^{[1,2,4]}$ Perichondrium is a diffuse connective tissue layer required for the growth and maintenance of the cartilage. It is rich in collagen and contains numerous fibroblasts. Chondroblasts found in the inner layer of perichondrium differentiate and form chondrocytes.

Defects occurring in the cartilage tissue due to various reasons lead to significant functional and esthetic problems which require replacement of the cartilage. ${ }^{[5]}$ Unfortunately, it is very difficult for chondrocytes embedded in matrix to migrate to the defect site so as to start repair process, so cartilage defects hardly heal and regenerate. ${ }^{[6]}$ Therefore, various materials have been used to repair the cartilage defects. Nowadays, mostly autogenous cartilage grafts have been used. ${ }^{[2,5]}$ In 1959 , Lester reported that perichondrium dissected away from the cartilage induced formation of new cartilage tissue. Since this discovery of chondrogenic characteristic of perichondrium, perichondrial grafts have been used with successful outcomes. ${ }^{[7]}$ Though in young patients these procedures have yielded good results, in some old patients frustrating outcomes have been obtained. These unfavorable results were associated with physiological changes in the cartilage and decrease in in the neochondrogenic potential with aging. ${ }^{[8]}$ If a larger area is damaged, then perichondrium cannot induce cartilage formation with due rapidity. In this case defect is closed with scar tissue which is formed by rapidly developing connective tissue. ${ }^{[3]}$ Therefore, a perichondrial neochondrogenesis faster than the developmental rate of scar tissue is critically important. ${ }^{[9]}$ Fascia lata has been used to enhance regeneration of the cartilage tissue with successful outcomes. The advantages of fascia lata include, its acceptance by the surrounding tissue without any complication, its biocompatibility and its collagenous and regenerative characteristics. ${ }^{[10-13]}$

In this study, the impact of fascia lata on perichondrial neochondrogenesis developed in defective areas of cartilages was investigated in a rabbit septum model.

\section{Materials and Methods Study Design}

Twenty adult New Zealand rabbits were studied in two groups with equal number of animals in each group. Anaesthesia was applied using $2 \mathrm{mg} / \mathrm{kg}$ xylazine hydrochloride (IM) and ketamine hydrochloride (IM). A median vertical incision was made on nasal dorsum from frontal bone up to nose tip. Nasal bone was retracted laterally from the midline to approach to the septum. Perichondrium was elevated bilaterally beginning from dorsal edge of the septum down to its base. Then full thickness cartilage with an area of $1 \mathrm{~cm}^{2}$ (Fig. 1) was resected to create a cartilage defect.

In Group 1, any material was not interposed between both leaflets of the perichondrium of the defective area. Bony parts were closed. Subcutaneous tissue and skin were closed with sutures before termination of the surgical procedure. This group was termed as the "control group."

Lateral aspects of the femoral region of ten rabbits were incised and after passing through skin and subcutaneous tissue, fascia lata was approached. A portion of the cartilage with the same size of the defect area was excised. Then this portion of the cartilage was interposed between both leaflets of the perichondrium and the surgical field was closed. This group was termed as "fascia lata" group.

\section{Outcome Parameters}

Rabbits were sacrificed on postoperative 90th days and their septa were totally excised. The harvested specimens were kept in $10 \%$ formaldehyde solution. They were then fixated and embedded in paraffin blocks. Afterwards, $5 \mu$ sec-

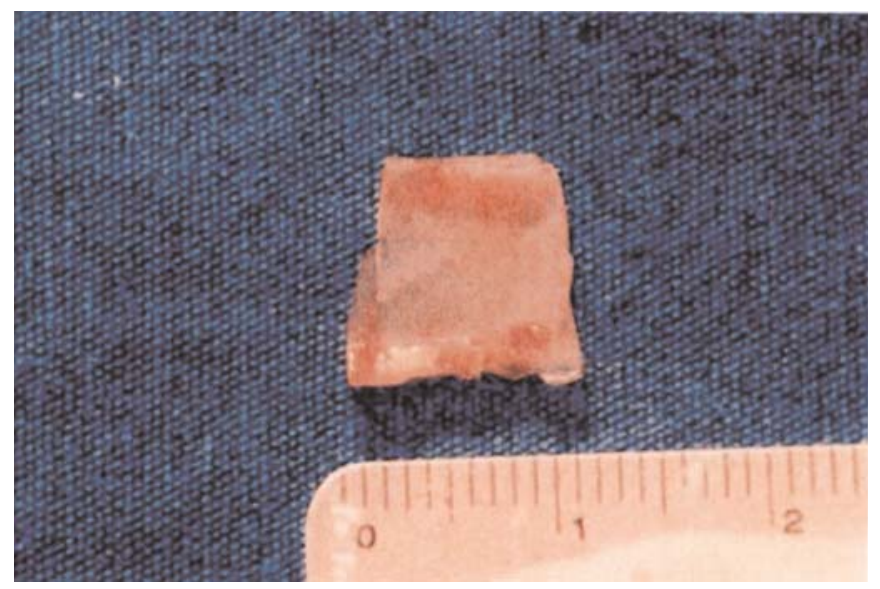

Fig. 1. Full thickness cartilage was resected with an area of $1 \mathrm{~cm}^{2}$ in size. 


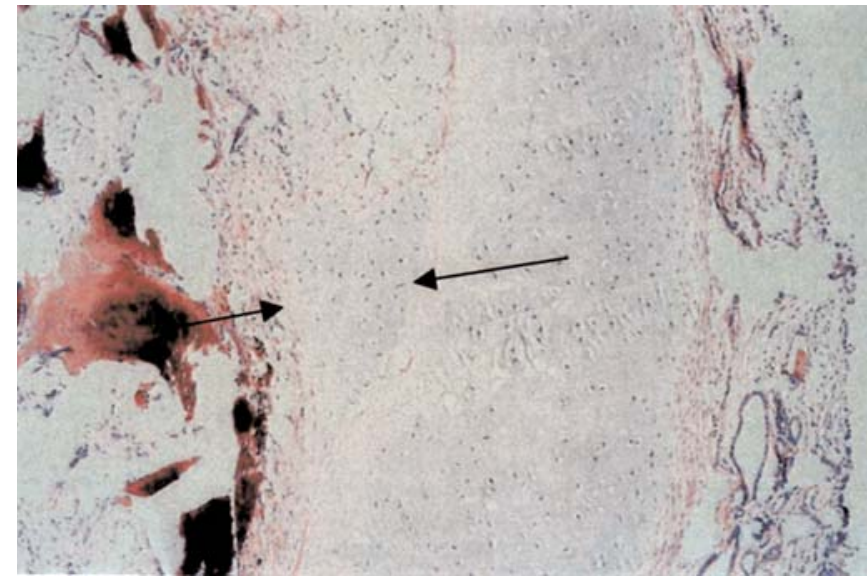

Fig. 2. Neochondrogenesis in the fascia lata group (HE $\times 100)$.

tions were cut using a microtome. The specimens were stained with hematoxylin-eosin and examined under $\times 1000$ magnification of a light microscope. The preparations were evaluated as for thickness of newly formed cartilage (in $\mathrm{mm}$ ), inflammatory reaction and presence of macroscopic perforation.

\section{Results}

During the study period, one rabbit from each group died and so excluded from the study. Areas of cartilage tissue were larger in the fascia lata group. In the middle of these areas basophilically stained chondroblasts and in the periphery acidophilic chondroblasts were observed. Newly formed cartilage and mature cartilage were distinctly separated from each other (Fig. 2). However, in the control group neochondrogenesis was restricted to small patchy areas. Relatively smaller number of chondrocytes was discerned around chondrocytes (Fig. 3). In both groups, chondroblasts were smaller than chondrocytes and also lacunes in mature cartilages were bigger than those in the areas of neochondrogenesis.

Median areas of neochondrogenesis in the control and fascia lata groups were 0.59 (range: $0.22-0.89$ ) $\mathrm{mm}$ and 1.35 (range: 0.36-2.32) $\mathrm{mm}$, respectively (Table 1 ). Thickness of the cartilage in the fascia lata group was sig-

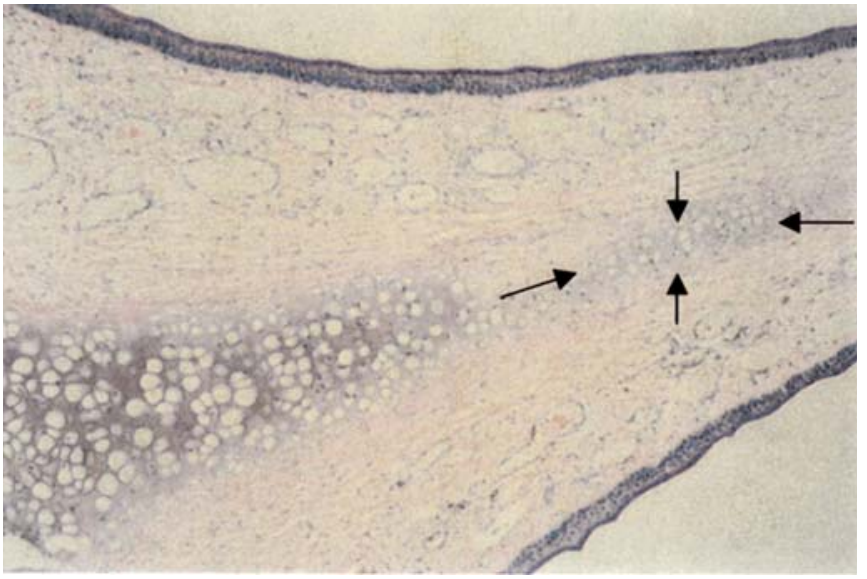

Fig. 3. Neochondrogenesis in the control group (HE $\times 100)$.

nificantly greater than that of the control group (M-W$\mathrm{U}=15,000, \mathrm{p}<0.05)$. Inflammatory reaction in the area of defect (Fig. 4) was detected in four $(4 / 9 ; 44.4 \%)$ rabbits in the control group and six $(6 / 9 ; 66.6 \%)$ rabbits in the fascia lata group (Table 1) without any significant difference between groups (Fischer's exact $=0.637, \mathrm{p}<0.05$ ). Necrotic areas (Fig. 5) were observed in four $(4 / 9 ; 44.4 \%)$ rabbits in the control and three $(3 / 9 ; 33.3 \%)$ rabbits in the fascia lata group without any significant difference between both groups (Fischer's exact $=0.637, \mathrm{p}<0.05) \quad$ (Table 1). Percentages of perforation were $55.5 \%$ (5/9) and $44.4 \%$ (4/9) in the control and fascia lata groups, respectively (Table 1), without any significant difference between the groups (Fischer's exact $=0.637, \mathrm{p}<0.05$ ).

\section{Discussion}

Various studies have demonstrated the presence of perichondrial induction of neochondrogenesis. ${ }^{[14]}$ Perichondrium adhered to the cartilage is not active. However, when it is separated from the cartilage, it becomes highly chondrogenic. $^{[15]}$

Perichondrium consists of two distinct layers as the outer thick fibrous layer and inner and thinner progenitor layer. It is a known fact that perichondrium also contains specific chondrocyte precursors. Ito et al. cultivated peri-

Table 1. Comparison of variables between groups.

\begin{tabular}{lccc}
\hline Groups & Thickness of the cartilage $(\mathbf{m m})$ & Inflammatory reaction & Necrotic areas \\
\hline Fascia lata & $1.35(0.36-2.32)$ & $66.6 \%(6 / 9)$ & $33.3 \%(3 / 9)$ \\
Control & $0.59(0.22-0.89)$ & $44.4 \%(4 / 9)$ & $44.4 \%(4 / 9)$ \\
\hline
\end{tabular}




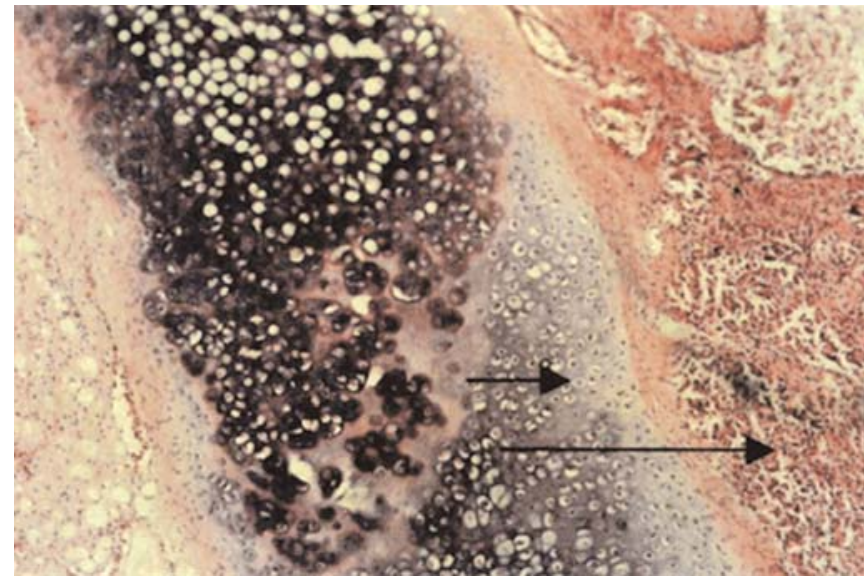

Fig. 4. Diffuse cartilage proliferation (short arrow) and inflammatory reaction in the surrounding tissue (long arrow) in the fascia lata group (HE $\times 100)$.

chondrial grafts harvested from rabbits and examined histomorphological changes. On 7th day, they detected chondrocytic differentiation, mRNA 2 and related proteins in the inner layer of the perichondrium without any change in the fibrous tissue.$^{[16]}$ Lopez Aguado et al. demonstrated neochondrogenesis and cartilage formation on the operation site following resection of subperichondrial layer from the septum. Neochondrogenesis and cartilage formation developed at regions far away from each other and transition zone between both tissues was made up of intermediate cells with chondrocytic and myofibroblastic characteristics. Since scar tissue starts to develop within the first 24 hours of the traumatic incident, it generally proceeds faster than neochondrogenetic repair. Therefore, in order to achieve maximum cartilage repair, it is mandatory to restrict bleeding and inflammation to minimize scar tissue formation. Proliferation and differentiation of chondrocytes, as seen in many cells, require an attachment site. Besides this attachment can facilitate the response of these cells to other regulatory factors. ${ }^{[5,17]}$

Various studies have been performed to accelerate neochondrogenesis. One part of these studies is related to autologuous mesenchymal cell implantation. ${ }^{[18]}$ The authors think that adequate number of repair cells should be available in the areas of defect for the repair of the cartilage tissue. Indeed, repair cells have the capability of repairing various cell types. When implanted in the defect, chondrogenic process rapidly starts to take effect. However this process may fail to induce development of complete cartilage tissue which might stem from inadequate amount of repair cells implanted in the area of defect. ${ }^{[19]}$

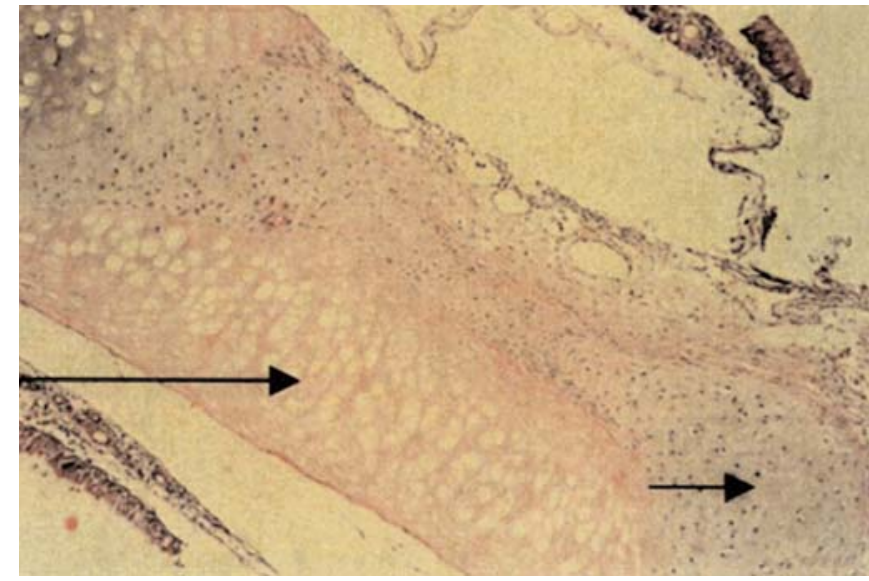

Fig. 5. Cartilage necrosis (long arrow) and new cartilage tissue (short arrow) in the fascia lata group (HE $\times 100)$

In studies targeting tissue regeneration, various materials have been used as regenerative tissue. Among them fascia lata is widely used. ${ }^{[10,20]}$ In a study performed with knee joints of the sheep, fascia lata was placed on the defective cartilage tissue and remodeling characterized by the increase in the number of fibrils, thickness of the collagen fibers of the fascia lata and foci of neochondrogenesis on the area of defect was detected. ${ }^{[11]}$ As a regenerative membrane, fascia lata was interposed between endosseous implant and bone allograft as a regenerative barrier membrane with resultant successful outcomes. ${ }^{[10]}$

Fascia lata is a partially acellular mesenchymal tissue containing longitudinal elastic and collagen fibrils with interspersed fibroblasts. ${ }^{[21]}$ Relative cellular deficit of fascia lata is its most important characteristic feature, which permits realization of successful tissue transplantation without any need for comparison and matching between donor and recipient sites. In a study on nasal septal perforation, fascia lata was used due to the requirement for a very low metabolic activity which allows tissue growth and vascularization on its surface. ${ }^{[13]}$ In studies performed, fascia lata has been recommended as a non-antigenic ideal donor graft. ${ }^{[1,22]}$

In this study autologous fascia lata graft was used. Fascia lata is easily available with low donor area morbidity. New cartilage formation was observed both in the control and the fascia lata groups. As supported by the studies performed, the rate of neochondrogenesis was statistically significantly higher in the control group. (M-W$\mathrm{U}=15,000, \mathrm{p}<0.05)$. The difference between both groups as for the rates of inflammatory reaction, necrosis and proliferation was not statistically significant. 
When evaluated together with literature findings, the results of this study support the assertion that perichondrial neochondrogenesis can greatly contribute to the repair of cartilage defects and use of fascia lata in the acceleration of this process can result in successful outcomes.

Conflict of Interest: No conflicts declared.

\section{References}

1. Lawrence WT, Potenza MS. Tissue transfer: fat, dermal, muscle, cartilage and fascial grafts. In: Cohen M, Goldwyn RM editor. Mastery of Plastic and Reconstructive Surgery. Vol. 1. London: Little, Brown and Company; 1994. p .88-94.

2. Brent, B. Repair and grafting of cartilage and perichondrium. In: McCarthy, JG, editor. Plastic surgery. Philadelphia: W. B. Saunders Co.; 1990. p. 559-80.

3. Silver FH, Glasgold AI. Cartilage wound healing. An overview. Otolaryngol Clin North Am 1995;28:847-64.

4. Gherardini G, Bathia N, Stal S. Costal cartilage grafts. In: Evans GRD, editor. Operative plastic surgery. New York: Mc GrawHill Company; 2000. p. 76-89.

5. Özbek S, Şen C, Kahveci Z, Özcan M. The effect of heterologous collagen in neochondrogenesis from free perichondrial grafts, in rabbits: an experimental study. [Article in Turkish] Ulus Travma Acil Cerrahi Derg 2003;9:17-22.

6. Duynstee MLG, Verwoed-Verhoef HL, Verwoed CDA, et al. The Dual role of perichondrium in cartilage wound healing. Plast Reconstr Surg 2002;110:1073-9.

7. Lester CW. Tissue replacement after subperichondrial resection of costal cartilage: two case reports. Plast Reconstr Surg Transplant Bull 1959;23:49-54.

8. Skoog T, Johansson SH. The formation of articuler cartilage from free perichondrial grafts. Plast Reconstr Surg 1976;57:1-6.

9. Bruns J, Kertsen P, Lierse W, Weiss A, Silbermann M. The in vitro influence of different culture conditions on the potential of sheep rib perichondrium to form hyaline-like cartilage. Evaluation of gluing materials used for in vivo graft fixation. Wirchows Archiv 1994;424:169-75.

10. Silverstein LH, Kraft JD, Wand R. Bone regeneration and tissue acceptance of human fascia lata grafts adjacent to dental implants: a preliminarycase report. J Oral Implantol 1992;18: 394-8.

11. Krol R, Barcew-Wiszniewska B. Morphological evaluation of fascia lata tissue implantation for chondral defects in the knee joint of sheep under active motion and load. [Article in Polish] Chir Narzadow Ruchu Ortop Pol 1991;56:129-33.

12. Bruno de Rezende Pinna, João Norberto Stavale, Paulo Augusto de Lima Pontes, Osíris de Oliveira Camponês do Brasil. Histological analysis of autologous fascia graft implantation into the rabbit voice muscle. Braz J Otorhinolaryngol 2011;77:185-90.

13. Yildirim G, Onar V, Sayin I, Onol SD, Aydin T. The reconstruction of nasal septal perforation with high density porous polyethylene covered with fascia lata: an experimental study on rabbit model. Clin Exp Otorhinolaryngol 2011;4:137-41.

14. Hosokawa K, Hata Y, Yano K, Matsuka K, Ito O. Inhibitory effect of mature cartilage on perichondrial neochondrogenesis. Ann Plast Surg 1989;23:155-8.

15. Ito Y, Fitzsimmons JS, Sanyal A, Mello MA, Mukherjee N, O'Driscoll SW. Localization of chondrocyte precursors in periosteum. Osteoarthritis Cartilage 2001;9:215-23.

16. Hosokawa K, Hata Y, Yano K, Matsuka K. Cartilage formation from perichondrium in a difusion chamber. Ann Plast Surg 1988;21:140-2.

17. Lopez Aguado D, Monserrat JR, Perez Piñero B, Campos Bañales ME, Gutierrez R, Diaz Flores L. Neochondrogenesis in the septal area after submucous cartilaginous resection. Acta Otolaryngol 1992;112:539-44.

18. Robenson D, Nevo Z. Articuler cartilage chondrocytes are more advantageous for regenerating hyaline-like cartilage than mesenchymal cells isolated from microfracture repairs. Cell Tissue Bank 2001;2:23-30.

19. Caplan AI, Elyaderani M, Mochizuki Y, Wakitani S, Goldberg VM. Principles of cartilage repair and regeneration. Clin Orthop Relat Res 1997;(342):254-69.

20. Thammavaram KV1, Benzel EC, Kesterson L. Fascia lata graft as a dural substitute in neurosurgery. South Med J 1990;83:634-6.

21. Fitzgerald MP, Mollenhauer J, Brubaker L. The antigenicity of fascia lata allografts. BJU Int 2000;86:826-8.

22. Ghoniem GM. Allograft sling material: is it the state of the art? Int Urogynecol J Pelvic Floor Dysfunct 2000;11:69-70.

This is an open access article distributed under the terms of the Creative Commons Attribution-NonCommercial-NoDerivs 3.0 Unported (CC BYNC-ND3.0) Licence (http://creativecommons.org/licenses/by-nc-nd/3.0/) which permits unrestricted noncommercial use, distribution, and reproduction in any medium, provided the original work is properly cited.

Please cite this article as: Yılmaz Ş, Bilkay Ö, Özdemir İ, Avc1 A, Adadan Güvenç I. Investigation of the effects of fascia lata on neochondrogenesis in a rabbit model. J Med Updates 2014;4(2):66-70. 